\title{
ROLE OF AUTONOMOUS MOTIVATION IN INCREASING PHYSICAL ACTIVITY AMONG PATIENTS WITH TYPE 2 DIABETES MELLITUS: A SYSTEMATIC REVIEW
}

\author{
Amalul Fadly Hasibuan'1), Pujiyanto²) \\ 1)Masters Program of Public Health, Universitas Indonesia \\ ${ }^{2}$ Department of Health Policy Administration, Faculty of Public Health, \\ Universitas Indonesia
}

\begin{abstract}
Background: Autonomous motivation and self-care competence play a key role in the proces of health behavior change including increasing physical activity. Physical activity is crucial for glycemic control and is beneficial for overall well-being of patients with type 2 diabetes as well. This study aimed to review systematically role of autonomous motivation in increasing physical activity among patients with type 2 diabetes mellitus.

Subjects and Method: A systematic review was conducted by searching published articles from 2015 to 2019 from databases including ProQuest, Science direct, Scopus,, and Springer Link. The keyword for this review was "Autonomous motivation", "Self Determination Theory", "Physical activity", and "Diabetes Mellitus type 2". The inclusion criteria were English, open acces, health worker, and public health. The dependent variable was physical activity. The independent variable was autonomous motivation. After review process 6 articles were included in this review.

Results: Four articles stated that the autonomous motivation increased the duration of physical activity. The implementation of physical activity in accordance with the recommendation of 150 minutes / week with moderate to severe intensity. An article autonomous motivation increased physichal activity. An article stated that the autonomous motivation increased physical activity among patient wit diabetes mellitus.

Conclusion: Autonomous motivation is an important factor in increasing adherence to physical activity according to recommendation.
\end{abstract}

Keywords: autonomous motivation, physical activity, type 2 diabetes mellitus

\section{Correspondence:}

Amalul Fadly Hasibuan, Masters Program in Public Health, Universitas Indonesia, Depok, West Java. Email: hasibuanfad@gmail.com, Mobile: 081259907343.

\section{BACKGROUND}

Diabetes Mellitus (DM) is a group of metabolic diseases characterized by hyperglycemia that occurs due to abnormalities in insulin secretion, the way insulin works or both (Perkeni, 2015). Type 1 DM (5-10\% of DM cases) is caused by auto immune disease; therefore, $\beta$-pancreatic cells do not produce enough insulin. Contrastingly, type 2 DM (90-95\% of cases) is caused by insulin resistance or impaired insulin secretion (Colberg et al., 2016).

Nowadays, Diabetes Mellitus becomes a serious problem. Globally, in 2013, there were 381.8 million people living with diabetes and it is likely to increase to 591.9 million in 2035. Diabetes prevalence in the World has doubled from $4.7 \%$ in 1980 to $8.5 \%$ in 2014. Diabetes caused 3.7 million deaths in 2012. 1.5 million deaths were caused by diabetes directly, while another 2.2 million deaths were caused by blood sugar levels that exceeded normal limits, thus increasing the risk of cardiovascular disease and other diseases. As many as $43 \%$ of 3.7 million deaths occurred before the age of 70 years. The percentage of deaths caused by diabetes that occurs before the age of 70 is higher in developing countries compared to developed countries (World Health Organization, 2018). 
DM is the third leading cause of death in Indonesia (Usman et al., 2018). Indonesia was ranking seventh highest in the world in 2015 for the prevalence of DM (World Health Organization, 2015). Based on data from the Basic Health Research in 2018, the prevalence of DM in the population over 15 years (DMT2) was 2\%. It increased compared to data from the Basic Health Research in 2013 which was $1.5 \%$ (Ministry of Health, 2013). However, the prevalence of DM according to the Perkeni (Indonesian Society for Endocrinology) in 2015, the DM cases at the age of $>15$ years in 2018 increased to $7.8 \%$ from the previous result by $6.9 \%$ in 2013 (Ministry of Health, 2018).

In general, physical activity is an important component in managing blood sugar and the health of DM patients (Colberg et al., 2016). Physical activity is beneficial in controlling blood glucose levels, reducing insulin resistance, increasing lipid profile, and reducing blood pressure and weight ( $\mathrm{Sn}$ owling and Hopkins, 2006) (Chudyk and Petrella, 2011).

The benefits of physical activity in DM patients have been widely recognized. However, there were only a few DM patients who carried out physical activities as recommended. For example, in Canada, there were only about $30 \%$ of adult DM patients carried out physical activity according to the recommendations. The Canadian Diabetes Association and the American Diabetes Associations recommend morning physical activity in diabetes patients, which is 150 minutes/week with moderate and severe intensity (Miquelon and Castonguay, 2016).

Health care workers need to find an effective approach, so that DMT patients can carry out physical activities according to recommendations. One of the approaches is the Self-Determination (SDT) theory. SDT is a theory about the continuum of human motivation in carrying out activities that consist of a motivation, controlled and autonomous motivation (Ryan and Deci, 2017).

The more autonomous human motivation, the more motivated a person is in carrying out an activity (Ryan and Deci, 2017). Motivation is a condition that someone has no desire to do activities. For example, someone does not carry out physical activity because they think it is very boring or not interesting. Controlled motivation is a condition of an individual who has little motivation in himself. Controlled motivation consists of internal and external motives. External motives are conditions of someone who carry out activities in order to please or get appreciation from others. Internal motive is a condition where a person carries out an activity due to pressure from himself to avoid guilty feelings or keep the self-esteem.

Autonomous motivation is a form of motivation occurs due to his desire. It consists of identified and intrinsic regulation. Identified is still part of external motivation. Identified is a motivation because there he considers that there are benefits gained when carrying out an activity. Intrinsic regulation is the most autonomous motivation, where a person does an activity because he feels interested and comfortable doing it (Miquelon and Castonguay, 2016; Ryan and Deci, 2017).

This study aimed to investigate the role of Autonomous Motivation in Increasing Physical Activity among Patients with Type 2 Diabetes Mellitus.

\section{SUBJECTS AND METHOD}

\section{Design of the study}

The subjects of this study were journal articles about the role of Autonomous Motivation in Increasing Physical Activity among Patients with Type 2 Diabetes Mellitus.

A systematic review was used as the method of this study with PRISMA-P (Preferred Reposting Items for Systematic Review 
and Meta-Analysis Protocol). The researchers conducted a search through 4 databases, namely Proquest, Science Direct, Scopus, and Springer Link. The keywords were "Autonomous motivation", "Self-Determination Theory", "Physical activity", "Diabetes Mellitus type $2 "$.

\section{Study Variables}

The dependent variable was physical activity. The independent variable was autonomous motivation.

\section{Inclusion and Exclusion Criteria}

The inclusion criteria were articles published in the last 5 years, using English, in the scope of health psychology and public health. Based on the search results, there were 6 articles that were relevant to review.

\section{RESULTS}

Based on the six articles examined, there was a close correlation between autonomous motivation and physical activity among patients with T2DM $(\mathrm{p}<0.001)$. Four articles showed that autonomous motivation was closely related to the adherence of patients with T2DM in carrying out physical activities in accordance with the guidelines, which was for 150 minutes/week with moderate to severe duration. Meanwhile, one article stated that autonomous motivation was closely related to the implementation of physical activity. In addition, another article stated that autonomous motivation was closely related to the success in increasing physical activity among patients with articles. There were three articles from six articles that divided autonomous motivation into two parts, namely identified and intrinsic regulation.

An articles stated that Identified $(\mathrm{OR}=$ 1.64, 95\%CI=1.01 to 2.67) was more influential in carrying out physical activity than Intrinsic regulation: $\mathrm{OR}=1.41,95 \% \mathrm{CI}=1.03$ to 1.93. However, one other article stated that intrinsic regulation $(b=0.16 ; 95 \% \mathrm{CI}=0.07$ to 0.24; $\mathrm{p}<0.001$ ) affected physical activity.

\section{DISCUSSION}

After studying the six articles, Autonomous motivation had a significant effect on the implementation of physical activity. This is in line with the initial prediction that states that the more autonomous a person's motivation is, the greater the effort made to engage and carry out these activities (Patrick and Williams, 2012). Autonomous motivation can be achieved when three basic psychological needs are met, namely, autonomy, competence and relatedness (Legault, 2017).

Autonomy is a person's need to have freedom in making choices according to his wishes without any intervention from others. Competence is a feeling of having the ability or capacity to do something. Meanwhile, relatedness is a feeling of feeling socially connected. Relatedness is an interrelationship between feelings of being cared for by others and feelings of belonging or meaning for others (Ryan and Deci, 2017).

Three articles divided autonomous motivation into two sub-types: identified and intrinsic regulation. An article stated that identified had more role in the implementation of physical activity. However, another article said that intrinsic had more role and identified did not have role. It is because autonomous motivation is a continuum. In addition, there is an internal regulation from external to internal states (Patrick and Williams, 2012). An article that stated that identified regulation played more important role because most patients did not consider physical activity as fun (Edmunds et al., 2006).

Some previous studies have opinions about which one has more roles, whether identified or internal regulation. Identified regulation is considered to have more roles in physical activity because physical activity must be carried out consistently and repeatedly. 


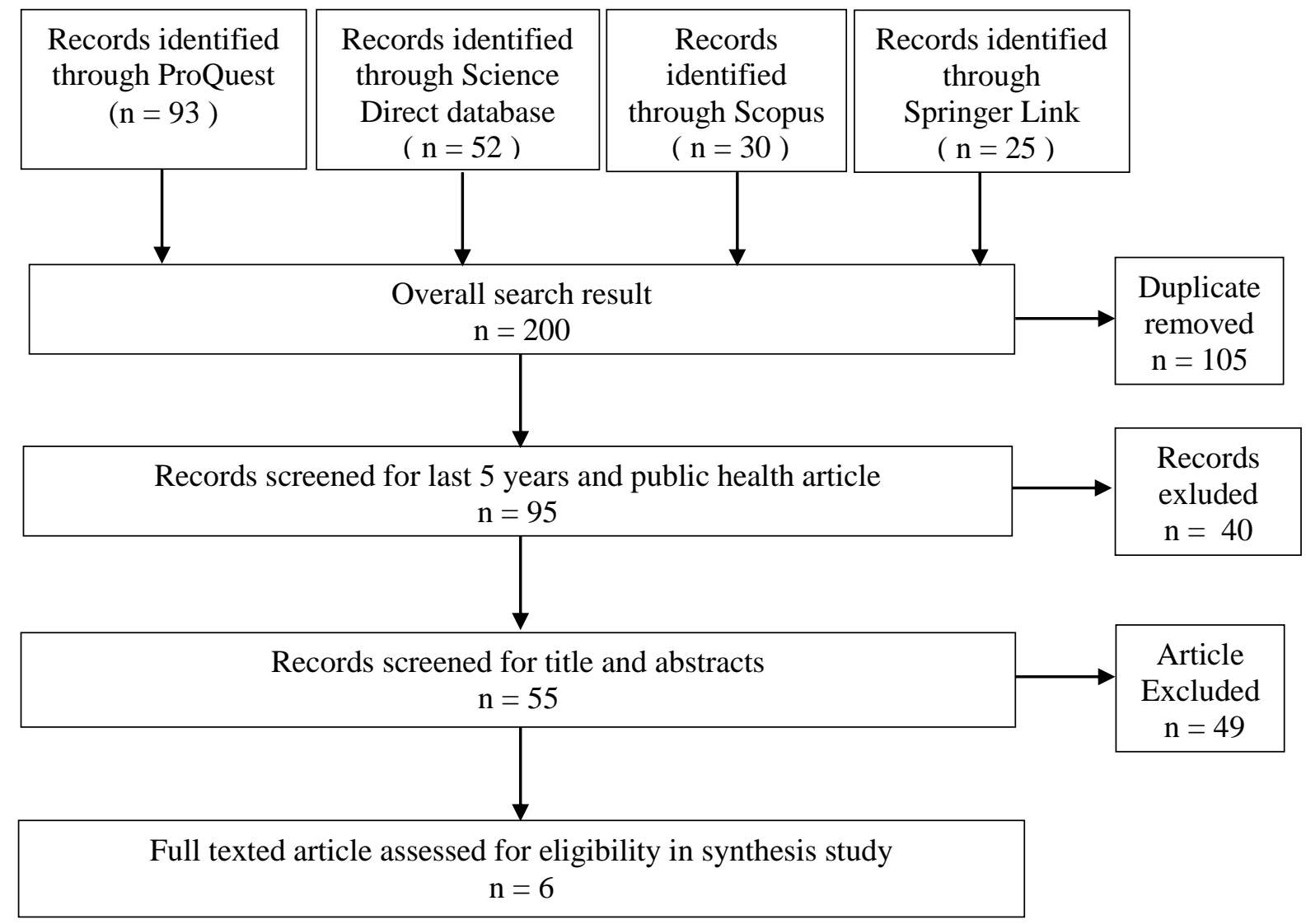

Figure 1. 2015 PRISMA protocol flow

It requires more effort, both physically and mentally. This kind of activities must have strong reasons in the form of results to be achieved such as the impacts on health (Edmunds et al., 2006).

Based on a study conducted by Silva et al. (2010), internal regulation was more consistent in predicting the implementation of physical activity in the long term compared to the identified regulation. In carrying out the intervention of Autonomous motivation, the health workers need to pay attention to these three basic needs. Therefore, the patients with DMT2 carry out physical activities as recommended. Autonomy support can be carried out by listening to patient opinions, giving advice with rational explanation, reducing control and judgment, exploring physical activity that is appropriate for the patient, and giving patients the choice to choose the intervention they want (Silva et al., 2008) (Patrick and Williams, 2012 ). This is in line with the recommendation of the American Diabetes Association (2018) in the management of patients with DM in the form of patient-center care intervention. The intervention is carried out by considering the patient's choices, values, and needs. The most important thing is that clinical decisions are taken based on the values patient have.

Support on the competence can be carried out by giving clear and honest information about the selected activity and its benefits (the benefits of physical activity on health), identifying the obstacles experienced by the patient, making an activity plan according to the patient's need, appreciating the patient's ability to carry out these activities (physical activity), motivating patients, and providing positive feedback (Silva et al., 2008; Patrick and Wiliams, 2012). 


\begin{tabular}{|c|c|c|c|c|c|c|c|}
\hline No & Articles & $\begin{array}{l}\text { Data } \\
\text { Base }\end{array}$ & Year & Author & $\begin{array}{c}\text { Study } \\
\text { Design }\end{array}$ & Results & Conclusion \\
\hline 1 & $\begin{array}{l}\text { Motives for Parti- } \\
\text { cipation in Phy- } \\
\text { sical Activity and } \\
\text { Observance of } \\
\text { Physical Activity } \\
\text { Recommendations } \\
\text { among Adults } \\
\text { with Type } 2 \text { Dia- } \\
\text { betes }\end{array}$ & $\begin{array}{l}\text { Canadian } \\
\text { Journal of } \\
\text { Diabetes }\end{array}$ & 2016 & $\begin{array}{l}\text { Miquelon et } \\
\text { al. }\end{array}$ & $\begin{array}{l}\text { Cross- } \\
\text { sectional }\end{array}$ & $\begin{array}{l}\text { There was a positive } \\
\text { correlation between } \\
\text { autonomous motivati- } \\
\text { on and the accumula- } \\
\text { tion of physical activi- } \\
\text { ty implementation of } \\
\text { at least } 150 \text { minutes/- } \\
\text { week with moderate to } \\
\text { severe intensity. } \\
\text { p<0.001 (Intrinsic } \\
\text { motives: OR=1.41, } \\
\text { 95\%CI=1.03 to } 1.93 \\
\text { Identified: OR=1.64, } \\
\text { 95\%CI=1.01 to } 2.66 \text { ) }\end{array}$ & $\begin{array}{l}\text { The efforts of health education } \\
\text { on the importance of motive } \\
\text { why we have to do physical acti- } \\
\text { vity and maintain it needs to be } \\
\text { a special concern for health } \\
\text { workers because the results of } \\
\text { this study indicate that patients } \\
\text { who do physical activity at least } \\
\text { 150 minutes/week with modera- } \\
\text { te to severe duration are } \\
\text { affected by identified and } \\
\text { intrinsic regulation }\end{array}$ \\
\hline 2 & $\begin{array}{l}\text { Determinants of } \\
\text { physical activity } \\
\text { among patients } \\
\text { with type } 2 \text { diabet- } \\
\text { es: the role of per- } \\
\text { ceived autonomy } \\
\text { support, autono- } \\
\text { mous motivation } \\
\text { and self-care com- } \\
\text { petence }\end{array}$ & $\begin{array}{l}\text { Psychology, } \\
\text { Health and } \\
\text { Medicine }\end{array}$ & 2017 & $\begin{array}{l}\text { Koponen et } \\
\text { al. }\end{array}$ & $\begin{array}{l}\text { Cross- } \\
\text { sectional }\end{array}$ & $\begin{array}{l}\text { Autonomous motiva- } \\
\text { tion was closely relat- } \\
\text { ed to physical activity, } \\
\text { even after being cont- } \\
\text { rolled by other factors. } \\
\text { p<0.001; OR=0.71; } \\
95 \% \mathrm{CI}=0.62 \text { to } 0.79\end{array}$ & $\begin{array}{l}\text { Health workers need to concen- } \\
\text { trate on supporting the patient's } \\
\text { autonomous motivation, so that } \\
\text { the management intervention of } \\
\text { autonomous motivation among } \\
\text { patients is successful }\end{array}$ \\
\hline 3 & $\begin{array}{l}\text { Motivational pro- } \\
\text { files for physical } \\
\text { activity among ad- } \\
\text { ults with type } 2 \\
\text { diabetes and their } \\
\text { relationships with } \\
\text { physical activity } \\
\text { behavior }\end{array}$ & $\begin{array}{l}\text { Health } \\
\text { Psychology } \\
\text { and } \\
\text { Behavioral } \\
\text { Medicine }\end{array}$ & 2017 & $\begin{array}{l}\text { Castonguay } \\
\text { and } \\
\text { Miquelon }\end{array}$ & $\begin{array}{l}\text { Cross- } \\
\text { sectional }\end{array}$ & $\begin{array}{l}\text { The implementation } \\
\text { of physical activity } \\
\text { matched the guideli- } \\
\text { nes related to intrinsic } \\
\text { and identified regula- } \\
\text { tion (autonomous } \\
\text { motivation) p<0.001 }\end{array}$ & $\begin{array}{l}\text { Health education regarding the } \\
\text { importance of patients with } \\
\text { T2DM to do PA should be done } \\
\text { more, so that they carry out PA } \\
\text { autonomously. }\end{array}$ \\
\hline
\end{tabular}

The $6^{\text {th }}$ International Conference on Public Health Best Western Premier Hotel, Solo, Indonesia, October 23-24, $2019 \mid 232$ 


\begin{tabular}{|c|c|c|c|c|c|c|c|}
\hline No & Articles & $\begin{array}{l}\text { Data } \\
\text { Base }\end{array}$ & Year & Author & $\begin{array}{c}\text { Study } \\
\text { Design }\end{array}$ & Results & Conclusion \\
\hline 4 & $\begin{array}{l}\text { Motivational pro- } \\
\text { files, accelerome- } \\
\text { ter-derived physi- } \\
\text { cal activity, and } \\
\text { acute diabetes- } \\
\text { related symptoms } \\
\text { in adults with type } \\
2 \text { diabetes }\end{array}$ & $\begin{array}{l}\text { BMC } \\
\text { Public } \\
\text { Health }\end{array}$ & 2018 & $\begin{array}{l}\text { Castonguay } \\
\text { and } \\
\text { Miquelon }\end{array}$ & $\begin{array}{l}\text { a cross- } \\
\text { sectional } \\
\text { design }\end{array}$ & $\begin{array}{l}\text { Intrinsic regulation } \\
\text { was positively related } \\
\text { to the implementation } \\
\text { of physical activity wi- } \\
\text { th moderate to severe } \\
\text { intensity every week } \\
(\mathrm{b}=0.16 ; 95 \% \mathrm{CI} 0.07 \\
\text { to } 0.24 ; \mathrm{p}<0.001)\end{array}$ & $\begin{array}{l}\text { Patients with T2DM who do } \\
\text { physical activity according to } \\
\text { the recommendations tend to } \\
\text { do so because they feel happy } \\
\text { doing it (intrinsic motive). The- } \\
\text { refore, it is important to promo- } \\
\text { te autonomous motive among } \\
\text { patients with T2DM in order to } \\
\text { carry out physical activities acc- } \\
\text { ording to the recommendations. }\end{array}$ \\
\hline 5 & $\begin{array}{l}\text { Relationships bet- } \\
\text { ween health litera- } \\
\text { cy, motivation and } \\
\text { diet and physical } \\
\text { activity in people } \\
\text { with type } 2 \text { diabet- } \\
\text { es participating in } \\
\text { peer-led support } \\
\text { groups }\end{array}$ & $\begin{array}{l}\text { Primary } \\
\text { Care } \\
\text { Diabetes }\end{array}$ & 2018 & Juul et al. & $\begin{array}{l}\text { Cross } \\
\text { sectional }\end{array}$ & $\begin{array}{l}\text { The implementation of } \\
\text { physical activity accor- } \\
\text { ding to recommenda- } \\
\text { tion was only statistica- } \\
\text { lly related to autono- } \\
\text { mous motivation } \\
(b=0.61 ; 95 \% \text { CI } 0.29 \text { to } \\
0.92 ; p<0.001)\end{array}$ & $\begin{array}{l}\text { This study shows that autonomo- } \\
\text { us motivation is the most influ- } \\
\text { ential factor for patients with } \\
\text { T2DM to do physical activity; } \\
\text { therefore, the concept of auton- } \\
\text { omous motivation is very rele- } \\
\text { vant to be implemented as an } \\
\text { intervention in patients with } \\
\text { T2DM. }\end{array}$ \\
\hline 6 & $\begin{array}{l}\text { Success in increa- } \\
\text { sing physical acti- } \\
\text { vity (PA) among } \\
\text { patients with type } \\
2 \text { diabetes: a self- } \\
\text { determination the- } \\
\text { ory perspective }\end{array}$ & $\begin{array}{l}\text { Health } \\
\text { Psychology } \\
\text { and } \\
\text { Behavioral } \\
\text { Medicine }\end{array}$ & 2018 & $\begin{array}{l}\text { Koponen et } \\
\text { al. }\end{array}$ & $\begin{array}{l}\text { Cross- } \\
\text { sectional } \\
\text { mail } \\
\text { survey }\end{array}$ & $\begin{array}{l}\text { Autonomous motivati- } \\
\text { on was likely to succe- } \\
\text { ed in increasing phy- } \\
\text { sical activity even after } \\
\text { being controlled by } \\
\text { other factors. } \\
(\mathrm{OR}=1.64 ; 95 \% \mathrm{CI} 1.46 \\
\text { to } 1.85 ; \mathrm{p}<0.001)\end{array}$ & $\begin{array}{l}\text { Autonomous motivation is the } \\
\text { most powerful predictor of suc- } \\
\text { cess in increasing physical acti- } \\
\text { vity. The interaction between } \\
\text { doctor and patient must focus on } \\
\text { promoting motivation from } \\
\text { oneself in changing and integra- } \\
\text { ting change in oneself. }\end{array}$ \\
\hline
\end{tabular}

The $6^{\text {th }}$ International Conference on Public Health Best Western Premier Hotel, Solo, Indonesia, October 23-24, 2019 | 233

https://doi.org/10.26911/the6thicph-FP.04.02 
Based on a study conducted by Hui and Xie (2014), there was a significant correlation between the level of knowledge about physical activity and the implementation of physical activity, where the higher the knowledge, the higher the level of duration of physical activity.

Relatedness can be fulfilled by giving support to the patients. Support from health workers, friends and family of patients is very helpful for patients in carrying out physical activity. Support is given by giving positive appreciation to patients, especially when they are not successful in doing physical activities, exploring problems faced by patients, showing empathy to problems faced by patients, providing a warm interpersonal environment, and also avoiding to blame and judge patients (Silva et al., 2008; Patrick and Wiliams, 2012).

Autonomous motivation is a very important factor in increasing the adherence among patients with T2DM in carrying out physical activities as recommended. Autonomous motivation can be achieved by paying attention to the three basic psychological needs of the patient, such as autonomy, competence and relatedness. Health workers need to provide support on the three basic psychological needs of patients with T2DM. It aims to internalize autonomous motivation, so that they are able to maintain physical activity according to the recommendation given which is 150 minutes/week with moderate to severe intensity.

\section{REFERENCES}

$\overline{\text { American Diabetes Association (2018). Ame- }}$ rican Diabetes Association. Pharmacologic approaches to glycemic treatment: Standards of Medical Care in Diabetes. Diabetes Care, 41(1): S73 LP-S85.

Castonguay A \& Miquelon P (2017). Motivational profiles for physical activity among adults with type 2 diabetes and their relationships with physical activity behavior. Health Psychology and Behavioral Medicine, 5(1): 110-128. https://doi.org/10.1080/21642850.201 6.1272416

Castonguay A, Miquelon P (2018). Motivational profiles, accelerometer-derived physical activity, and acute diabetes-related symptoms in adults with type 2 diabetes. BMC Public Health, 18(1): 115. https://doi.org/10.1186/s12889-0185376-y

Chudyk A, Petrella RJ(2011). Effects of exercise on cardiovascular risk factors in type 2 diabetes: A meta-analysis. Diabetes Care, 34(5): 1228-1237. https://doi.org/10.2337/dc10-1881

Colberg SR, Sigal RJ, Yardley JE, Riddell MC, Dunstan DW, Dempsey PC, Tate DF (2016). Physical Activity / Exercise and Diabetes : A Position Statement of the American Diabetes Association. 39: 2065-2079. https://doi.org/10.2337/dc16-1728

Deci EL \& Ryan RM (2017). Self-Determination Theory: Basic Psychological Needs in Motivation Development and Wellness. In New York: Guilford Publishing. https://doi.org/10.1097/TA.obo13e31827e1534

Edmunds J, Ntoumanis N, \& Duda J L (2006). A test of self-determination theory in the exercise domain. Journal of Applied Social Psychology, 36(9): 22402265. https://doi.org/10.1111/j.00219029.2006.00102.x

Hui SSC, Hui GPS, Xie YJ (2014). Association between Physical Activity Knowledge and Levels of Physical Activity in Chinese Adults with Type 2 Diabetes. PLoS ONE, 9(12): e115098. https://doi.org/10.1371/journal.pone.0115098

Juul L, Rowlands G, Maindal HT (2018). Relationships between health literacy, motivation and diet and physical activity 
in people with type 2 diabetes participating in peer-led support groups. Primary Care Diabetes: 12(4), 331-337. https://doi.org/10.1016/j.pcd.2018.o2.005

Koponen AM, Simonsen N, \& Suominen S (2017). Determinants of physical activity among patients with type 2 diabetes: The role of perceived autonomy support, autonomous motivation and self-care competence. Psychology, Health and Medicine, 22(3): 332-344. https://doi.org/10.1080/13548506.2016.1154179

Koponen AM, Simonsen N, \& Suominen S (2018). Success in increasing physical activity (PA) among patients with type 2 diabetes: A self-determination theory perspective. Health Psychology and Behavioral Medicine, 6(1): 104-119. https://doi.org/10.1080/21642850.2018.1462707

Legault L (2017). Self-Determination Theory BT - Encyclopedia of Personality and Individual Differences (V. Zeigler-Hill \& TK. Shackelford, Eds.). https://doi.org/10.1007/978-3-319-28099-8_1162-1

Ministry of Health (2013). Riset Kesehatan Dasar 2013. Riskesdas 2013. https://doi.org/10.1517/13543784.7.5.803

Ministry of Health (2018). Laporan Nasional Riskesdas 2018. Riskesdas 2018, 182183.

Miquelon P \& Castonguay A (2016). Motives for Participation in Physical Activity and Observance of Physical Activity Recommendations among Adults with Type 2 Diabetes. Canadian Journal of Diabetes, 40(5): 399-405. https://doi.org/10.1016/j.jcjd.2016.02.009

Patrick H \& Williams GC (2012). Self-determination theory: Its application to health behavior and complementarity with motivational interviewing. International Journal of Behavioral Nutrition and Physical Activity, 9: 1-12. https://doi.org/10.1186/1479-5868-9-18

Perkeni (2015). Pengelolaan dan pencegahan diabetes melitus tipe 2 di indonesia 2015. Jakarta: PB. PERKENI.

Silva MN, Markland D, Minderico CS, Vieira PN, Castro MM, Coutinho SR, Teixeira PJ (2008). A randomized controlled trial to evaluate self-determination theory for exercise adherence and weight control: Rationale and intervention description. BMC Public Health, 8: 1-13. https://doi.org/10.1186/1471-2458-8-234

Silva MN, Markland D, Vieira PN, Coutinho SR, Carraça EV, Palmeira AL, Teixeira PJ (2010). Helping overweight women become more active: Need support and motivational regulations for different forms of physical activity. Psychology of Sport and Exercise, 11(6): 591-601. https://doi.org/10.1016/j.psychsport.2010.06.011

Snowling NJ \& Hopkins WG (2006). Effects of different modes of exercise training on glucose control and risk factors for complications in type 2 diabetic patients: A meta-analysis. Diabetes Care, 29(11): 2518-2527. https://doi.org/10.2337/dco6-1317

Usman Y, Iriawan RW, Rosita T, Lusiana M, Kosen S, Kelly M, Rao C (2018). Indonesia's sample registration system in 2018: A work in progress. Journal of Population and Social Studies, 27(1): 39-52. https://doi.org/10.25133/JPSSV27N1.003

World Health Organization (2015). Diabetes Melitus Fakta dan Angka di Indonesia. World Health Organization (2018). Global Report on Diabetes. In Global Report on Diabetes. France: WHO Press. 